\title{
PENINGKATAN KETERAMPILAN MENULIS TEKS DESKRIPSI MELALUI PENDEKATAN SAINTIFIK DENGAN METODE MIND MAPPING
}

\author{
Wilda Suryani \\ UPTD SMP Negeri 5 Kecamatan Lareh Sago Halaban, Kabupaten Lima Puluh Kota \\ email: wildasuryani676@gmail.com
}

\begin{abstract}
This research was a Classroom Action Research which consists of two cycles. The background of this research was that the level of the students' writing skill of descriptive text was generally low. The research subjects were students of class VII.A SMP Negeri 5 Lareh Sago Halaban District. The research was conducted in the Odd Semester of the 2019/2020 Academic Year. Qualitative data were collected through observations and field notes. Quantitative data in the form of learning outcomes to write descriptive texts were obtained through exercises or assignments. Based on the research that has been done, it is found that the use of a scientific approach with mind mapping method can significantly improve the skills of students in writing descriptive texts.
\end{abstract}

Keywords: Writing Skills, Descriptive Text, Scientific Approach, and Mind Mapping

\begin{abstract}
ABSTRAK
Penelitian ini adalah Penelitian Tindakan Kelas yang terdiri dari dua siklus. Latar belakang penelitian adalah tingkat keterampilan menulis teks deskripsi peserta didik umumnya rendah. Subyek penelitian adalah peserta didik kelas VII.A SMP Negeri 5 Kecamatan Lareh Sago Halaban. Penelitian dilaksanakan pada Semester Ganjil Tahun Pelajaran 2019/2020. Data kualitatif dikumpulkan melalui observasi dan catatan lapangan. Data kuantitaif yang berupa hasil belajar menulis teks deskripsi diperoleh melalui latihan atau tugas. Berdasarkan penelitian yang telah dilakukan diperoleh hasil bahwa penggunaan pendekatan saintifik dengan metode mind mapping dapat meningkatkan keterampilan peserta didik dalam menulis teks deskripsi secara signifikan.
\end{abstract}

Kata Kunci: Keterampilan Menulis, Teks Deskripsi, Pendekatan Saintifik, dan Mind Mapping

\section{PENDAHULUAN}

Konsep kurikulum termuat dalam Undang-undang Sistem Pendidikan Nasional (UUSPN) Nomor 20 Tahun 2003, yang menyatakan bahwa kurikulum adalah seperangkat rencana dan pengaturan mengenai tujuan, isi, dan bahan pembelajaran yang digunakan sebagai pedoman penyelenggaraan kegiatan pembelajaran untuk mencapai tujuan pendidikan tertentu. Kurikulum sebagai pedoman untuk mencapai tujuan pendidikan, menurut Husamah dan Yanuar (2013:5) bukan sekadar meningkatkan kualitas sumber daya manusia untuk memenuhi kebutuhan tenaga terampil untuk pembangunan fisik, tetapi lebih kepada pembentukan sikap mental dan karakter yang menjadi pondasi bagi kehidupan peseta didik di masa depan. Tantangan di masa depan juga semakin canggih, kompleks, dan menuntut respon perubahan. 
Acuan dan prinsip penyusunan kurikulum 2013 mengacu pada pasal 36 Undang-Undang Nomor 20 Tahun 2003, yang menyatakan bahwa penyusunan kurikulum harus memerhatikan peningkatan iman dan taqwa: peningkatan akhlak mulia; peningkatan potensi;kecerdasan, dan minat peserta didik; keragaman potensi daerah dan lingkungan; tuntunan pembangunan daerah dan nasional; tntunan dunia kerja; perkembangan ilmu pengetahuan, teknologi, dan seni; agama; dinamika perkembangan global; dan persatuan nasional dan nilai-nilai kebangsaan.

Salah satu kompetensi yang harus dikuasai oleh peserta didik kelas VII SMP dalam kurikulum 2013 adalah menulis teks deskripsi secara tertulis yang terdapat pada kompetensi dasar 4.2 Menyajikan data, gagasan, kesan dalam bentuk teks deskripsi tentang objek (sekolah, tempat wisata, tempat bersejarah, dan/atau suasana pentas seni daerah) secara tulis dan lisan dengan memperhatikan struktur, kebahasaan baik secara lisan maupun tulis. Hal ini sesuai dengan Finoza (2005:3-4) yang menyatakan bahwa perwujudan bahasa berdasarkan cara berkomunikasi ada dua, yaitu ragam lisan dan ragam tulis. Semi (2003: 29-47) bahwa salah satu bentuk atau jenis tulisan adalah tulisan deskripsi, dimana deskripsi adalah tulisan yang bertujuan memberikan rincian atau detail tentang objek sehingga dapat memberikan pengaruh pada sensitivitas dan imajinasi pembaca dan pendengar sehingga mereka bagaikan ikut melihat, mendengar, merasakan atau mengalami objek tersebut. Keterampilan menyajikan teks deskripsi secara tertulis menuntut peserta didik mampu menyampaikan data dan fakta yanag didengar dan dilihat ke dalam bentuk teks deskripsi sehingga keterampilan menyampaikan suatu fakta dan pendapat tentang suatu peristiwa dapat berkembang.

Berdasarkan pengalaman penulis sebagai pendidik Bahasa Indonesia di SMP Negeri 5 Kecamatan Lareh Sago Halaban, ternyata terdapat kendala dalam pelaksanaan pembelajaran Bahasa Indonesia berdasarkan kurikulum 2013. Proses pembelajaran sulit untuk diterapkan karena peserta didik kurang aktif dalam mengikuti pembelajaran. Permasalahan tersebut terjadi karena peserta didik sudah terbiasa dengan pembelajaran yang berbasis ilmu bahasa sehingga sulit menyesuaikan dengan pembelajaran yang berbasis teks. Penyebab lainnya dikarenakan di dalam diri peserta didik masih kurang ditanamkan sikap percaya diri dan tanggungjawab, akibatnya peserta didik masih ragu-ragu dalam menyampaikan pendapatnya. Ketika proses pembelajaran berlangsung peserta didik hanya menggunakan bahasa Indonesia sekadar sebagai alat komunikasi.

Kendala yang paling sulit dalam pencapaian empat kompetensi inti yang ada adalah kompetensi yang berkaitan dengan keterampilan. Hal tersebut disebabkan peserta didik mengalami kesulitan dalam menentukan pilihan kata yang tepat, menulis teks secara runtut, dan menulis paragraf yang kohesif. Terlebih dalam menulis teks deskripsi secara tertulis, terdapat tiga struktur yang isi dari tiap bagian memiliki kesamaan, bahkan peserta didik sulit untuk membedakan mana yang seharusnya bagian identifikasi, klasifikasi/definisi, atau deskripsi bagian. Hal ini dibuktikan dengan nilai hasil tes keterampilan menulis teks deskripsi secara tertulis, hanya beberapa peserta didik yang dapat mencapai Kriteria Ketuntasan Minimal (KKM). Hasil ini masih jauh dari kriteria 75\% dari jumlah peserta didik yang seharusnya berhasil mencapai KKM. Ini berarti sebanyak 20 
peserta didik dari jumlah peserta didik belum mampu mencapai KKM yang telah ditetapkan kemendikbud, yaitu dengan nilai $\geq 70$.

Kurikulum 2013 menekankan pada dimensi pedagogik modern dalam pembelajaran, yaitu menggunakan saintifik (ilmiah) Pendekatan ilmiah dalam pembelajaran meliputi menggali informasi melalui pengamatan, bertanya, percobaan, kemudian mengolah data atau informasi menyajkan data atau informasi, dilanjutkan dengan menganalisis, menalar, kemudian menyimpulkan, dan mencipta (Kemenduikbud 2013:148-149). Pembelajaran dengan pendekatan saintifik melatih peserta didik untuk berpikir ilmiah bukan hanya dalam pembelajaran tetapi juga diharapkan dalam kehidupan yang dijalaninya, oleh karena itu ketepatan perlu ditingkatkan untuk keberhasilan peserta didik dalam menulis teks deskripsi secara tertulis.

Berdasarkan hal tersebut sesuai dengan kurikulum 2013 yang menekankan pembelajaran menggunakan pendekatan saintifik agar peserta didik bisa lebih berkembang, maka penelitian ini menggunakan media dalam pembelajaran. Menurut Gangean Brig (Arsyad 1997:4) bahwa media pembelajaran meliputi alatalat yang secara fisik dapat digunakan untuk menyampaikan isi materi pembelajara yang terdiri dari buku, tape recorder, kaset, video, kamera film, foto, grafik, gambar, televisi dan computer. Dalam penelitian ini metode yang digunakan yaitu metode Mind Mapping dalam pendekatan saintifik. Penggunaan Mind Mapping dalam proses pembelajaran dapat melatih peserta didik untuk berpikir analitis, menjelaskan sesuatu dengan sistematika, dan menggunakan logika yang tepat.

Dengan memperkenalkan cara belajar yang baru kepada peserta didik dapat mendorong semangat peserta didik dalam proses belajar dan juga sebagai variasi pembelajaran sehingga peserta didik menjadi lebih tertarik. Metode Mind Mapping dibentuk dari gagasan-gagasan yang berbentuk peta pikiran yang dapat disesuaikan dengan struktur teks deskripsi, yaitu deskripsi umum, dan deskripsi bagian, akan tetapi hal tersebut belum tergambar dengan jelas. Oleh karena itu penulis tertarik melakukan penelitian dengan judul "Peningkatan Keterampilan Menulis Teks Deskripsi melalui Pendekatan Saintifik dengan Metode Mind Mapping di Kelas VII.A SMP Negeri 5 Kecamatan Lareh Sago Halaban Semester Ganjil Tahun Pelajaran 2019/2020"

Dalam melaksanakan metode Mind Mapping dibutuhkan media yang sesuai dengan metode, maka penggunaan media dalam menulis teks deskripsi secara tertulis dipilih sebagai penyalur ide bagi peserta didik. Gambar dapat menjadi dasar penulisan teks deskripsi, sebab peserta didik dapat mendeskripsikan objek yang menjadi tema dalam menulis teks deskripsi melalui gambar yang diamati. Hal tersebut disebabkan terbatasnya waktu dan biaya untuk melakukan pengamatan langsung terhadap budaya yang dideskripsikan dalam teks deskripsi .

Penelitian ini dilakukan untuk meningkatkan keterampilan peserta didik di kelas VII.A SMP Negeri 5 dalam menulis teks deskripsi secara tertulis menggunakan pendekatan saintifik melalui metode Mind Mapping. Jika hasilnya maksimal, maka diharapkan pendidik lain juga dapat menerapkannya untuk meningkatkan keberhasilan peserta didik dalam menulis teks dskripsi. 


\section{METODOLOGI}

Penelitian ini merupakan Penelitian Tindakan Kelas (PTK). Penelitian tindakan kelas ini dilaksanakan di kelas VII.A SMPN 5 Lareh Sago Halaban yang terletak di Jorong Kampai Kenagarian Sitanang Kecamatan Lareh Sago Halaban. Penelitian Tindakan kelas ini dilaksanakan pada bulan Juli tahun pelajaran 2019/2020 dan membutuhkan waktu 6 bulan. Subjek penelitian adalah peserta didik kelas VII.A SMPN 5 Lareh Sago Halaban Tahun Pelajaran 2019/2020 dengan jumlah peserta didik yang terdiri dari 20 orang, dengan rincian 12 laki-laki dan 8 orang perempuan. Instrumen yang digunakan untuk melaksanakan penelitian adalah 1) lembar observasi aktivitas pendidik dan peserta didik selama pembelajaran berlangsung, 2) lembaran tes menulis teks deskripsi yang digunakan untuk melihat penguasaan konsep-konsep materi pembelajaran tentang langkah menulis teks deskripsi.

Indikator keberhasilan dalam penelitian ini adalah sebagai berikut:

1. Apabila rata-rata hasil keterampilan peserta didik dalam menulis teks deskripsi lebih dari 75 pembelajaran dapat dikatakan berhasil dan tidak dilanjutkan ke siklus berikutnya.

2. Apabila rata-rata hasil keterampilan peserta didik dalam menulis teks deskripsi kurang dari 75 pembelajaran belum berhasil sehingga perlu dilanjutkan ke siklus berikutnya. Nilai rata-rata adalah jumlah nilai seluruhnya dibagi jumlah peserta didik yang diteliti.

Tes keterampilan berupa tugas menulis teks deskripsi dinilai bedasarkan aspek isi teks, struktur teks, kosa kata, penggunaan bahasa dan mekanik. Skor penilaian untuk masing-masing aspek dapat dilihat pada Tabel berikut.

Tabel 1. Penilaian Keterampilan

\begin{tabular}{|c|l|c|}
\hline No & \multicolumn{1}{|c|}{ Aspek yang dinilai } & Jumlah Skor \\
\hline 1 & Isi Teks & 30 \\
\hline 2 & Organisasi/ struktur teks & 20 \\
\hline 3 & Kosa kata & 20 \\
\hline 4 & Penggunaan bahasa & 20 \\
\hline 5 & Mekanik Jumlah & 10 \\
\hline \multicolumn{2}{|c|}{} \\
\hline
\end{tabular}

Penilaian keterampilan dari beberapa aspek di atas dibagi berdasarkan skor yang sesuai dengan kemampuan peserta didik. Dari hasil skor yang diperoleh oleh peserta didik dapat dilihat bagaimana peserta didik dalam bidang keterampilannya dalam menulis teks deskripsi secara tertulis. Dalam menilai hasil tes peserta didik, telah ditentukan rentang skor dan kategori penilaian keterampilan menulis teks deskripsi secara tertulis sebagai berikut:

Tabel 2. Rentang Skor dan kategori Penilaian

\begin{tabular}{|c|l|c|}
\hline No & \multicolumn{1}{|c|}{ Kategori } & Rentang Nilai \\
\hline 1 & Sangat baik & $90-100$ \\
\hline 2 & Baik & $75-89$ \\
\hline 3 & Cukup baik & $60-74$ \\
\hline 4 & Kurang & $25-59$ \\
\hline 5 & Sangat kurang & $0-24$ \\
\hline
\end{tabular}




\section{HASIL PENELITIAN DAN PEMBAHASAN}

\section{Pra siklus}

Aktivitas belajar peserta didik kelas VII.A cendrung rendah dan monoton. Hal ini ditandai dengan peserta didik lebih senang dicermahi, peserta didik sedikit sekali yang mau bertanya dan sedikit pula yang mampu menjawab pertanyaan, dan contoh-contoh materi pelajaran yang diberikan pendidik masih kurang terkait dengan lingkungan sehari-hari peserta didik. Hal inilah yang menyebabkan nilai rata-rata hasil belajar menulis teks deskripsi menjadi rendah yaitu 68,55, seperti tertera pada tabel di bawah ini.

Tabel 3. Data Keterampilan Menulis teks Deskripsi Peserta Didik Pra Siklus

\begin{tabular}{|c|c|c|c|c|c|c|c|}
\hline \multirow[b]{2}{*}{ No } & \multirow[b]{2}{*}{ Responden } & \multicolumn{5}{|c|}{ Skor Berdasarkan Aspek Penilaian } & \multirow{2}{*}{$\begin{array}{c}\text { Jumlah } \\
\text { Skor } \\
\text { Mak } \\
(100)\end{array}$} \\
\hline & & $\begin{array}{l}\text { Isi } \\
\text { (30) }\end{array}$ & $\begin{array}{c}\text { Organisasi } \\
\text { (20) }\end{array}$ & $\begin{array}{l}\text { Kosa } \\
\text { Kata } \\
(20)\end{array}$ & $\begin{array}{c}\text { Penggunaan } \\
\text { Bahasa } \\
(20)\end{array}$ & $\begin{array}{c}\text { Mekanik } \\
\text { (10) }\end{array}$ & \\
\hline 1 & A & 20 & 9 & 8 & 18 & 7 & 68 \\
\hline 2 & B & 10 & 16 & 20 & 15 & 10 & 71 \\
\hline 3 & $\mathrm{C}$ & 18 & 10 & 15 & 15 & 10 & 68 \\
\hline 4 & $\mathrm{D}$ & 16 & 20 & 14 & 15 & 6 & 71 \\
\hline 5 & $\mathrm{~F}$ & 26 & 15 & 16 & 10 & 5 & 72 \\
\hline 6 & $\mathrm{G}$ & 26 & 16 & 15 & 17 & 6 & 80 \\
\hline 7 & $\mathrm{H}$ & 22 & 17 & 18 & 10 & 5 & 72 \\
\hline 8 & I & 23 & 8 & 16 & 20 & 5 & 72 \\
\hline 9 & $\mathrm{~J}$ & 20 & 10 & 11 & 15 & 8 & 64 \\
\hline 10 & $\bar{K}$ & 25 & 10 & 15 & 15 & 5 & 70 \\
\hline 11 & $\mathrm{~L}$ & 26 & 14 & 10 & 15 & 5 & 70 \\
\hline 12 & $\mathrm{M}$ & 20 & 15 & 15 & 14 & 8 & 72 \\
\hline 13 & $\mathrm{~N}$ & 10 & 10 & 17 & 10 & 5 & 52 \\
\hline 14 & $\mathrm{O}$ & 18 & 15 & 15 & 12 & 6 & 66 \\
\hline 15 & $\mathrm{P}$ & 20 & 15 & 20 & 10 & 5 & 70 \\
\hline 16 & $\mathrm{Q}$ & 18 & 19 & 15 & 12 & 7 & 71 \\
\hline 17 & $\mathrm{R}$ & 15 & 19 & 17 & 10 & 10 & 71 \\
\hline 18 & $S$ & 14 & 9 & 7 & 15 & 5 & 50 \\
\hline 19 & $\mathrm{~T}$ & 19 & 15 & 15 & 9 & 8 & 70 \\
\hline 20 & $\mathrm{U}$ & 20 & 17 & 16 & 15 & 15 & 71 \\
\hline & \multicolumn{6}{|c|}{ Jumlah Nilai } & 1371 \\
\hline & \multicolumn{6}{|c|}{ Rata-rata } & 68,55 \\
\hline & \multicolumn{6}{|c|}{ Kategori } & $\begin{array}{c}\text { Cukup } \\
\text { Baik }\end{array}$ \\
\hline
\end{tabular}

Rendahnya keterampilan menulis teks deskripsi peserta didik, maka dilakukan suatu tindakan yaitu pendekatan saintifik dengan metode mind mapping.

\section{Siklus 1}

1) Perencanaan

Sebelum kegiatan dilakukan di dalam kelas, terlebih dahulu disusun rencana kegiatan dalam siklus I, yaitu sebagai berikut:

a) Mempersiapkan Rencana Pelaksanaan Pembelajaran (RPP).

b) Membagi kelompok peserta didik. 
c) Mempersiapkan latihan yang dikerjakan peserta didik baik pribadi maupun kelompok. Materi yang diberikan adalah materi semester satu kelas VII yaitu KD 4.2 yaitu menyajikan data, gagasan, kesan dalam bentuk teks deskripsi tentang objek (sekolah, tempat wisata, tempat bersejarah dan atau suasana pentas seni daerah) secara tertulis dan lisan dengan memerhatikan struktur, kebahasaan baik secara lisan dan tulis.

d) Mempersiapkan instrumen penelitian.

2) Pelaksanaan

Penelitian ini dilaksanakan dalam tiga kali pertemuan. Dua pertemuan pembelajaran tatap muka dan satu pertemuan tes keterampilan menulis teks deskriptif peserta didik. Pelaksanaan pembelajaran siklus I yaitu dengan langkah-langkah sebagai berikut:

- Pada tahap pendahuluan peneliti menyampaikan tujuan pembelajaran yang meliputi langkah-langkah menulis teks deskripsi.

a) Meyampaikan tujuan pembelajaran, yang mencakup langkah-langkah menulis teks deskripsi.

b) Memotivasi peseta didik dengan menjelaskan pentingnya materi untuk memhami materi selanjutnya dan menerapkannya dalam kehidupan sehari-hari.

c) Memberikan tugas kelompok.

- Pada tahap kegiatan inti peneliti melakukan sebagai berikut

a) Peneliti mengkomunikasikan materi tentang metode menulis teks deskripsi dengan metode Mind Mapping.

b) Setiap kelompok disuruh untuk menentukan sebuah kata kunci dan mendiskusikan unsur-unsur yang berkaitan dengan kata kunci tersebut dalam bentuk mind mapping. Selama proses pembelajaran komunikasi antar peserta didik dalam kelompoknya dalam mencari unsur-unsur tersebut.

c) Pendidik terus memantau aktivitas peserta didik dan mengarahkan ketika ada kelompok yang kesulitan menemukan unsur-unsur dari kata kunci tersebut dan mengembangkan nya menjadi teks deskripsi.

d) Memimpin diskusi kelas di mana masing-masing wakil kelompok mengemukakan pendapatnya atas unsur-unsur dan dalam mengembangkan unsur-unsur menjadi teks deskripsi.

- Kegiatan Penutup

a) Menyimpulkan atas hasil data yang diberikan oleh masing-masing kelompok

b) Memberikan masalah tambahan untuk menghubungkan materi pelajaran yang diberikan saat itu dengan kehidupan sehari-hari.

c) Memberikan tugas yang diambil dari latihan yang terdapat dalam buku paket dan penunjang lainnya.

Berikut data keterampilan menulis teks deskripsi setelah diberikan tindakan pada siklus I secara lengkap dapat penulis paparkan pada tabel 4 di bawah ini: 
Tabel 4. Data Keterampilan Menulis teks Deskripsi Peserta Didik Siklus I

\begin{tabular}{|c|c|c|c|c|c|c|c|}
\hline \multirow[b]{2}{*}{$\begin{array}{l}\mathrm{N} \\
\mathrm{O}\end{array}$} & \multirow[b]{2}{*}{$\begin{array}{c}\text { Respon } \\
\text { den }\end{array}$} & \multicolumn{5}{|c|}{ Skor Berdasarkan Aspek Penilaian } & \multirow{2}{*}{$\begin{array}{c}\text { Jumlah } \\
\text { Skor } \\
\text { Mak } \\
(100) \\
\end{array}$} \\
\hline & & $\begin{array}{l}\text { Isi } \\
(30)\end{array}$ & $\begin{array}{l}\text { Organisasi } \\
\text { (20) }\end{array}$ & $\begin{array}{l}\text { Kosa } \\
\text { Kata } \\
(20)\end{array}$ & $\begin{array}{c}\text { Penggunaan } \\
\text { Bahasa } \\
(20)\end{array}$ & $\begin{array}{c}\text { Mekanik } \\
\text { (10) }\end{array}$ & \\
\hline 1 & $\mathrm{~A}$ & 20 & 15 & 15 & 18 & 7 & 75 \\
\hline 2 & B & 20 & 16 & 15 & 14 & 7 & 72 \\
\hline 3 & $\mathrm{C}$ & 21 & 10 & 15 & 15 & 9 & 70 \\
\hline 4 & $\mathrm{D}$ & 16 & 20 & 14 & 15 & 6 & 71 \\
\hline 5 & $\mathrm{~F}$ & 29 & 15 & 16 & 10 & 5 & 70 \\
\hline 6 & $\mathrm{G}$ & 26 & 16 & 17 & 17 & 9 & 85 \\
\hline 7 & $\mathrm{H}$ & 24 & 17 & 18 & 10 & 5 & 71 \\
\hline 8 & I & 21 & 15 & 14 & 15 & 7 & 72 \\
\hline 9 & $\mathbf{J}$ & 29 & 10 & 11 & 15 & 6 & 72 \\
\hline 10 & $\mathrm{~K}$ & 25 & 10 & 15 & 15 & 5 & 70 \\
\hline 11 & $\mathrm{~L}$ & 24 & 14 & 10 & 15 & 7 & 70 \\
\hline 12 & $\mathrm{M}$ & 22 & 14 & 14 & 14 & 8 & 72 \\
\hline 13 & $\mathrm{~N}$ & 20 & 14 & 14 & 15 & 5 & 68 \\
\hline 14 & $\mathrm{O}$ & 22 & 15 & 15 & 15 & 6 & 72 \\
\hline 15 & $\mathrm{P}$ & 20 & 15 & 15 & 14 & 8 & 72 \\
\hline 16 & Q & 18 & 19 & 15 & 12 & 7 & 71 \\
\hline 17 & $\mathrm{R}$ & 20 & 16 & 17 & 10 & 8 & 71 \\
\hline 18 & $\mathrm{~S}$ & 20 & 14 & 13 & 12 & 8 & 67 \\
\hline 19 & $\mathrm{~T}$ & 19 & 16 & 15 & 14 & 8 & 72 \\
\hline \multirow[t]{4}{*}{20} & $\mathrm{U}$ & 20 & 15 & 14 & 15 & 8 & 72 \\
\hline & \multicolumn{6}{|c|}{ Jumlah Nilai } & 1436 \\
\hline & \multicolumn{6}{|c|}{ Rata-rata } & 71,80 \\
\hline & \multicolumn{6}{|c|}{ Kategori } & $\begin{array}{c}\text { Cukup } \\
\text { Baik }\end{array}$ \\
\hline
\end{tabular}

3) Observasi

Selama kegiatan pembelajaran, observer membantu mengamati pelaksanaan tindakan, baik dalam penyajian yang diberikan oleh pendidik maupun tindakan peserta didik. Pendidik mengamati aktivitas peserta didik baik soal bekerja individu maupun bekerja secara kelompok dalam menyelesaikan soal-soal latihan. Pendidik mencatat kejadian-kejadian penting saat peserta didik bekerja, baik yang bersifat positif maupun negatif. Pendidik dan observer mendiskusikan hasil observasi.

Hasil observasi aktivitas pendidik pada siklus I yaitu sebagai berikut:

\section{Tabel 5 . Hasil Observasi Aktivitas Pendidik pada Siklus I}

\begin{tabular}{|c|l|c|c|}
\hline \multirow{2}{*}{ No } & \multicolumn{1}{|c|}{ Aktivitas } & \multicolumn{2}{|c|}{ Keterlaksanaan } \\
\cline { 3 - 4 } & \multicolumn{1}{|c|}{$\begin{array}{c}\text { Pert. 1 } \\
\text { Pert. 2 }\end{array}$} \\
\hline 1 & $\begin{array}{l}\text { Mengkomunikasikan materi tentang metode } \\
\text { menulis teks deskripsi dengan metode Mind } \\
\text { Mapping }\end{array}$ & $\sqrt{ }$ & $\sqrt{ }$ \\
\hline 2 & $\begin{array}{l}\text { Meminta setiap kelompok disuruh untuk } \\
\text { menentukan sebuah kata kunci dan mendiskusikan } \\
\text { unsur-unsur yang berkaitan dengan kata kunci }\end{array}$ & $\sqrt{ }$ & \\
\hline
\end{tabular}




\begin{tabular}{|c|l|c|c|}
\hline \multirow{2}{*}{ No } & \multicolumn{1}{|c|}{ Aktivitas } & \multicolumn{2}{c|}{ Keterlaksanaan } \\
\cline { 3 - 4 } & Pert. 1 & Pert. 2 \\
\hline 3 & $\begin{array}{l}\text { Persebut dalam bentuk mind mapping. } \\
\text { dan mengarahkan ketika ada kelompok yang } \\
\text { kesulitan menemukan unsur-unsur dari kata kunci } \\
\text { tersebut dan mengembangkan nya menjadi teks } \\
\text { deskripsi. }\end{array}$ & $\sqrt{ }$ & $\sqrt{ }$ \\
\hline 4 & $\begin{array}{l}\text { Memimpin diskusi kelas dimana masing-masing } \\
\text { wakil kelompok mengemukakan pendapatnya atas } \\
\text { unsur-unsur dan dalam mengembangkan unsur- } \\
\text { unsur menjadi teks deskripsi }\end{array}$ & $\sqrt{ }$ & $\sqrt{ }$ \\
\hline 5 & $\begin{array}{l}\text { Menyimpulkan atas hasil data yang diberikan oleh } \\
\text { masing-masing kelompok }\end{array}$ & 4 & 5 \\
\hline \multicolumn{1}{|c|}{ Jumlah } & $80 \%$ & $100 \%$ \\
\hline
\end{tabular}

Dari tabel 5 diatas terlihat bahwa persentase aktivitas guru pada siklus I pertemuan satu yaitu sebesar $80 \%$ dan pada pertemuan kedua meningkat menjadi 100\%. Untuk aktivitas peserta didik dapat dilihat pada tabel 6 berikut.

Tabel 6. Hasil Observasi Aktivitas Peserta Didik Siklus I

\begin{tabular}{|c|c|c|c|c|c|}
\hline \multirow[t]{2}{*}{ No } & \multirow[t]{2}{*}{ Aktivitas } & \multicolumn{2}{|c|}{$\begin{array}{l}\text { Ketercapaian } \\
\text { Pertemuan } 1\end{array}$} & \multicolumn{2}{|c|}{$\begin{array}{l}\text { Ketercapaian } \\
\text { Pertemuan } 2\end{array}$} \\
\hline & & $\mathrm{F}$ & $\%$ & $\mathrm{~F}$ & $\%$ \\
\hline 1 & $\begin{array}{l}\text { Perhatian peserta didk } \\
\text { terhadap aktivitas belajar }\end{array}$ & 15 & $75 \%$ & 18 & $90 \%$ \\
\hline 2 & $\begin{array}{l}\text { Keaktifan peserta didik } \\
\text { dalam berdiskusi }\end{array}$ & 8 & $40 \%$ & 12 & $60 \%$ \\
\hline 3 & $\begin{array}{l}\text { Keaktifan peserta didik } \\
\text { bertanya }\end{array}$ & 7 & $35 \%$ & 8 & $40 \%$ \\
\hline 4 & $\begin{array}{l}\text { Keaktifan peserta didik } \\
\text { menjawab pertanyaan }\end{array}$ & 7 & $35 \%$ & 8 & $40 \%$ \\
\hline 5 & $\begin{array}{l}\text { Kemampuan peserta didik } \\
\text { mengorganisasi struktur teks }\end{array}$ & 8 & $7 \%$ & 10 & $50 \%$ \\
\hline 6 & $\begin{array}{l}\text { Kemampuan peserta didik } \\
\text { menguasai kosa kata }\end{array}$ & 9 & $45 \%$ & 12 & $60 \%$ \\
\hline 7 & $\begin{array}{l}\text { Kemampuan peserta didik } \\
\text { penggunaan ejaan }\end{array}$ & 8 & $40 \%$ & 11 & $55 \%$ \\
\hline 8 & $\begin{array}{l}\text { Kemampuan menyajikan } \\
\text { teks secara lisan dan tulisan }\end{array}$ & 9 & $45 \%$ & 12 & $60 \%$ \\
\hline 9 & Kemampuan menelaah teks & 8 & $40 \%$ & 10 & $50 \%$ \\
\hline & Rata-rata & & $40.22 \%$ & & $56.11 \%$ \\
\hline
\end{tabular}

Dari tabel 6 terlihat bahwa persentase aktivitas peserta didik siklus I pada pertemuan 1 adalah $40.22 \%$ dan pertemuan 2 adalah sebesar $56.11 \%$. 
4) Refleksi

Analisis dan refleksi ini dilakukan setelah pembelajaran berlangsung, observer dan peneliti berdiskusi tentang kelemahan-kelemahan yang berkaitan dengan pembelajaran pada siklus I. Hasil refleksi peserta didik baru memperoleh nilai rata-rata 71,80. Berdasarkan hasil refleksi di atas, maka perlu dicarikan alternatif perbaikan dari permasalahan yang timbul dengan menyempurnakan tindakan yang dipilih dan meningkatkan keadaan yang telah lebih baik pada siklus I.

\section{Siklus 2}

Prosedur penelitian dalam siklus II terdiri dari perencanaan, tindakan, observasi, dan refleksi.

1) Perencanaan

Perencanaan ini mencakup menyiapkan tindakan yang sudah direvisi dalam mengantisipasi kelemahan-kelemahan pada siklus I.

a) Mempersiapkan Rencana Pelaksanaan Pembelajaran (RPP).

b) Membagi kelompok peserta didik.

c) Mempersiapkan latihan yang dikerjakan peserta didik baik pribadi maupun kelompok.

d) Mempersiapkan instrumen penelitian.

2) Pelaksanaan

Siklus II dilaksanakan sebanyak 3 x pertemuan, yaitu dua kali pertemuan tatap muka dan satu kali tes. Pada dasarnya pelaksanaan proses pembelajaran pada siklus II sama halnya dengan siklus I. Pelaksanaan pembelajaran pada siklus II adalah melakukan perbaikan dalam proses pembelajaran.

- Pada tahap pendahuluan peneliti menyampaikan tujuan pembelajaran yang meliputi langkah-langkah menulis teks deskripsi.

a) Meyampaikan tujuan pembelajaran, yang mencakup langkah-langkah menulis teks deskripsi.

b) Memotivasi peseta didik dengan menjelaskan pentingnya materi untuk memhami materi selanjutnya dan menerapkannya dalam kehidupan sehari-hari.

c) Memberikan tugas kelompok.

- Pada tahap kegiatan inti peneliti melakukan sebagai berikut

a) Peneliti mengkomunikasikan materi tentang metode menulis teks deskripsi dengan metode Mind Mapping.

b) Setiap kelompok disuruh untuk menentukan sebuah kata kunci dan mendiskusikan unsur-unsur yang berkaitan dengan kata kunci tersebut dalam bentuk mind mapping. Selama proses pembelajaran komunikasi antar peserta didik dalam kelompoknya dalam mencari unsur-unsur tersebut.

c) Pendidik terus memantau aktivitas peserta didik dan mengarahkan ketika ada kelompok yang kesulitan menemukan unsur-unsur dari kata kunci tersebut dan mengembangkan nya menjadi teks deskripsi.

d) Memimpin diskusi kelas di mana masing-masing wakil kelompok mengemukakan pendapatnya atas unsur-unsur dan dalam mengembangkan unsur-unsur menjadi teks deskripsi. 
- Kegiatan Penutup

a) Menyimpulkan atas hasil data yang diberikan oleh masing-masing kelompok

b) Memberikan masalah tambahan untuk menghubungkan materi pelajaran yang diberikan saat itu dengan kehidupan sehari-hari.

c) Memberikan tugas yang diambil dari latihan yang terdapat dalam buku paket dan penunjang lainnya.

Hasil belajar peserta didik yang ditunjukkan dengan nilai peserta didik hasil tugas pada akhir siklus II ternyata dari 20 orang jumlah peserta didik, hanya 1 orang yang $(5 \%)$ yang memperoleh nilai di bawah 7,00 dengan skor terendah 64 dan tertinggi 86 dengan nilai rata-rata 80,00. Berikut hasil belajar setelah diberikan tindakan pada siklus II secara lengkap dapat penulis paparkan pada tabel di bawah ini.

Tabel 7. Data Keterampilan Menulis teks Deskripsi Peserta Didik Siklus

\begin{tabular}{|c|c|c|c|c|c|c|c|}
\hline \multirow[b]{2}{*}{ No } & \multirow[b]{2}{*}{$\begin{array}{c}\text { Respon } \\
\text { den }\end{array}$} & \multicolumn{5}{|c|}{ Skor Berdasarkan Aspek Penilaian } & \multirow[b]{2}{*}{$\begin{array}{c}\text { Jumlah Skor } \\
\text { maksimal } \\
(100)\end{array}$} \\
\hline & & $\begin{array}{c}\text { Isi } \\
\text { (30) }\end{array}$ & $\begin{array}{l}\text { Organi } \\
\text { sasi } \\
(20)\end{array}$ & $\begin{array}{l}\text { Kosa } \\
\text { Kata } \\
(20)\end{array}$ & $\begin{array}{c}\text { Penggu } \\
\text { naan } \\
\text { Bahasa } \\
(20)\end{array}$ & $\begin{array}{c}\text { Meka } \\
\text { nik } \\
(10)\end{array}$ & \\
\hline 1 & A & 24 & 16 & 16 & 16 & 9 & 81 \\
\hline 2 & B & 24 & 16 & 16 & 16 & 7 & 79 \\
\hline 3 & $\mathrm{C}$ & 24 & 16 & 16 & 15 & 8 & 79 \\
\hline 4 & $\mathrm{D}$ & 24 & 16 & 15 & 16 & 8 & 79 \\
\hline 5 & $\mathrm{~F}$ & 26 & 15 & 16 & 15 & 8 & 80 \\
\hline 6 & $\mathrm{G}$ & 26 & 18 & 18 & 17 & 10 & 89 \\
\hline 7 & $\mathrm{H}$ & 25 & 17 & 17 & 16 & 7 & 82 \\
\hline 8 & I & 23 & 16 & 16 & 15 & 9 & 79 \\
\hline 9 & $\mathrm{~J}$ & 23 & 16 & 16 & 15 & 9 & 79 \\
\hline 10 & $\mathrm{~K}$ & 23 & 16 & 16 & 16 & 8 & 79 \\
\hline 11 & $\mathrm{~L}$ & 25 & 17 & 16 & 15 & 8 & 81 \\
\hline 12 & $\mathrm{M}$ & 25 & 17 & 17 & 17 & 8 & 80 \\
\hline 13 & $\mathrm{~N}$ & 26 & 16 & 15 & 15 & 8 & 80 \\
\hline 14 & $\mathrm{O}$ & 23 & 16 & 16 & 15 & 8 & 81 \\
\hline 15 & $\mathrm{P}$ & 24 & 16 & 16 & 16 & 8 & 80 \\
\hline 16 & $Q$ & 24 & 16 & 16 & 16 & 8 & 82 \\
\hline 17 & $\mathrm{R}$ & 24 & 17 & 17 & 17 & 7 & 82 \\
\hline 18 & $\mathrm{~S}$ & 19 & 15 & 14 & 14 & 7 & 69 \\
\hline
\end{tabular}




\begin{tabular}{|c|c|c|c|c|c|c|c|}
\hline \multirow[b]{2}{*}{ No } & \multirow[b]{2}{*}{$\begin{array}{c}\text { Respon } \\
\text { den }\end{array}$} & \multicolumn{5}{|c|}{ Skor Berdasarkan Aspek Penilaian } & \multirow[b]{2}{*}{$\begin{array}{c}\text { Jumlah Skor } \\
\text { maksimal } \\
(100)\end{array}$} \\
\hline & & $\begin{array}{c}\text { Isi } \\
\text { (30) }\end{array}$ & $\begin{array}{l}\text { Organi } \\
\text { sasi } \\
(20)\end{array}$ & $\begin{array}{l}\text { Kosa } \\
\text { Kata } \\
(20)\end{array}$ & $\begin{array}{c}\text { Penggu } \\
\text { naan } \\
\text { Bahasa } \\
(20)\end{array}$ & $\begin{array}{c}\text { Meka } \\
\text { nik } \\
(10)\end{array}$ & \\
\hline \multirow[t]{5}{*}{19} & $\mathrm{~T}$ & 25 & 16 & 16 & 16 & 8 & 81 \\
\hline & $\mathrm{U}$ & 23 & 16 & 16 & 16 & 8 & 79 \\
\hline & \multicolumn{6}{|c|}{ Jumlah Nilai } & 1601 \\
\hline & \multicolumn{6}{|c|}{ Rata-rata } & 80,05 \\
\hline & \multicolumn{6}{|c|}{ Kategori } & Baik \\
\hline
\end{tabular}

3) Observasi

Selama kegiatan pembelajaran, observer membantu mengamati pelaksanaan tindakan, baik dalam penyajian yang diberikan oleh pendidik maupun tindakan peserta didik. Pendidik mengamati aktivitas peserta didik baik soal bekerja individu maupun bekerja secara kelompok dalam menyelesaikan soal-soal latihan. Pendidik mencatat kejadian-kejadian penting saat peserta didik bekerja, baik yang bersifat positif maupun negatif. Pendidik dan observer mendiskusikan hasil observasi.

Hasil observasi aktivitas peserta didik pada siklus II dapat dilihat pada Tabel berikut.

\section{Tabel. Hasil Observasi Aktivitas Pendidik pada Siklus II}

\begin{tabular}{|c|c|c|c|}
\hline \multirow{2}{*}{ No } & \multirow{2}{*}{ Aktivitas } & \multicolumn{2}{|c|}{ Keterlaksanaan } \\
\hline & & Pert. 1 & Pert. 2 \\
\hline 1 & $\begin{array}{l}\text { Mengkomunikasikan materi tentang metode } \\
\text { menulis teks deskripsi dengan metode Mind } \\
\text { Mapping }\end{array}$ & $\sqrt{ }$ & $\sqrt{ }$ \\
\hline 2 & $\begin{array}{l}\text { Meminta setiap kelompok disuruh untuk } \\
\text { menentukan sebuah kata kunci dan mendiskusikan } \\
\text { unsur-unsur yang berkaitan dengan kata kunci } \\
\text { tersebut dalam bentuk mind mapping. }\end{array}$ & $\sqrt{ }$ & $\sqrt{ }$ \\
\hline 3 & $\begin{array}{l}\text { Pendidik terus memantau aktivitas peserta didik } \\
\text { dan mengarahkan ketika ada kelompok yang } \\
\text { kesulitan menemukan unsur-unsur dari kata kunci } \\
\text { tersebut dan mengembangkan nya menjadi teks } \\
\text { deskripsi. }\end{array}$ & $\sqrt{ }$ & $\sqrt{ }$ \\
\hline 4 & $\begin{array}{l}\text { Memimpin diskusi kelas dimana masing-masing } \\
\text { wakil kelompok mengemukakan pendapatnya atas } \\
\text { unsur-unsur dan dalam mengembangkan unsur- } \\
\text { unsur menjadi teks deskripsi }\end{array}$ & $\sqrt{ }$ & $\sqrt{ }$ \\
\hline 5 & $\begin{array}{l}\text { Menyimpulkan atas hasil data yang diberikan oleh } \\
\text { masing-masing kelompok }\end{array}$ & $\sqrt{ }$ & $\sqrt{ }$ \\
\hline & Jumlah & 5 & 5 \\
\hline & Persentase & $100 \%$ & $100 \%$ \\
\hline
\end{tabular}


Dari tabel 8 diatas terlihat bahwa persentase aktivitas guru pada siklus II pertemuan satu dan 2 yaitu $100 \%$. Untuk aktivitas peserta didik dapat dilihat pada tabel 9 berikut.

Tabel 9. Hasil Observasi Aktivitas Peserta Didik Siklus II

\begin{tabular}{|c|c|c|c|c|c|}
\hline \multirow{2}{*}{ No } & \multirow{2}{*}{ Aktivitas } & \multicolumn{2}{|c|}{$\begin{array}{l}\text { Ketercapaian } \\
\text { Pertemuan } 1\end{array}$} & \multicolumn{2}{|c|}{$\begin{array}{l}\text { Ketercapaian } \\
\text { Pertemuan } 2\end{array}$} \\
\hline & & $\mathrm{F}$ & $\%$ & $\mathrm{~F}$ & $\%$ \\
\hline 1 & $\begin{array}{l}\text { Perhatian peserta didk } \\
\text { terhadap aktivitas belajar }\end{array}$ & 19 & $95 \%$ & 20 & $100 \%$ \\
\hline 2 & $\begin{array}{l}\text { Keaktifan peserta didik } \\
\text { dalam berdiskusi }\end{array}$ & 14 & $70 \%$ & 16 & $80 \%$ \\
\hline 3 & $\begin{array}{l}\text { Keaktifan peserta didik } \\
\text { bertanya }\end{array}$ & 10 & $50 \%$ & 12 & $60 \%$ \\
\hline 4 & $\begin{array}{l}\text { Keaktifan peserta didik } \\
\text { menjawab pertanyaan }\end{array}$ & 13 & $65 \%$ & 15 & $75 \%$ \\
\hline 5 & $\begin{array}{l}\text { Kemampuan peserta didik } \\
\text { mengorganisasi struktur } \\
\text { teks }\end{array}$ & 13 & $65 \%$ & 16 & $80 \%$ \\
\hline 6 & $\begin{array}{l}\text { Kemampuan peserta didik } \\
\text { menguasai kosa kata }\end{array}$ & 16 & $80 \%$ & 18 & $90 \%$ \\
\hline 7 & $\begin{array}{l}\text { Kemampuan peserta didik } \\
\text { penggunaan ejaan }\end{array}$ & 14 & $70 \%$ & 15 & $75 \%$ \\
\hline 8 & $\begin{array}{l}\text { Kemampuan menyajikan } \\
\text { teks secara lisan dan tulisan }\end{array}$ & 14 & $70 \%$ & 17 & $85 \%$ \\
\hline 9 & Kemampuan menelaah teks & 13 & $65 \%$ & 15 & $75 \%$ \\
\hline & Rata-rata & & $0.00 \%$ & & $80.00 \%$ \\
\hline
\end{tabular}

Dari tabel 6 terlihat bahwa persentase aktivitas peserta didik siklus II pada pertemuan 1 adalah $70 \%$ dan pertemuan 2 adalah sebesar $80 \%$.

4) Refleksi

Dari analisis data di atas sudah tergambar adanya peningkatan hasil belajar bahasa Indonesia pada materi menulis teks deskripsi, hal ini dibuktikan dengan meningkatnya nilai rata-rata peserta didikmulai dari kondisi awal, siklus I hingga ke siklus II. Peneliti beserta pengamat memutuskan untuk menghentikan penelitian ini pada siklus II, karena sudah dianggap berhasil mencapai indikator keberhasilan yang sudah ditetapkan. Namun demikian peneliti berusaha terus meningkatkan untuk lebih meningkatkan hasil belajar dengan penerapan inovasi-inovasi baru pada proses pembelajaran.

Berdasarkan data hasil pengamatan hasil tugas akhir siklus II dan diskusi peneliti dengan observer ternyata pembelajaran Bahasa Indonesia pada materi menulis teks deskripsi melalui pendekatan saintifik metode Mind Mapping memberikan manfaat yang cukup baik. Hal ini dapat dilihat dari catatan sebagai berikut:

a) Aktivitas peserta didik tampak baik di mana mereka lebih sibuk mencari unsur-unsur yang berkaitan dengan kata kunci dan menuliskannya di Mind 
Mapping dengan sungguh-sungguh mengembangkannya menjadi sebuah teks.

b) Peserta didik yang pandai tidak menonjol dalam kelompok. Peneliti sudah berhasil memotivasi peserta didik yang berada pada tingkat bawah untuk bisa lebih aktif dalam mengemukakan pendapatnya.

c) Suasana kelas sudah lebih terkontrol, karena pada siklus II kegiatan belajar peserta didik dibagi menjadi 4 kelompok. masing-masing kelompok mengerjakan 1 Mind Mapping dan jumlah anggota tiap kelompok 4-5 orang. Sehingga waktu untuk mengerjakan tugas lebih lama.

\section{Pembahasan}

Aktivitas peserta didik pada siklus pertama sudah bergeser dari kondisi awal sebelum dilakukan tindakan namun belum maksimal. Pada kegiatan menyusun potongan teks belum seluruh anggota kelompok mengikuti. Masih ada peserta didik yang tidak mau tahu dengan apa yang dikerjakan teman dan menerima saja hasil yang sudah dibuat. Kegiatan kerjasama ataupun diskusi yang dilaksanakan pada siklus I masih didominasi oleh beberapa orang peserta didik. Peserta didik yang tampil berbicara itu ke itu saja dan peserta didik yang berada di level bawah masih malu-malu untuk mengungkapkan pendapatnya.

Sedangkan pada siklus II peserta didik menjadi lebih aktif, termotivasi, lebih tertantang untuk belajar, muncul sikap positif dan berkurang sikap negatifnya. Peserta didik lebih sering aktif ikut menyusun potongan-potongan teks dan mencari unsur-unsur yang berhubungan dengan kata kunci, berinteraksi dengan teman sekelompok dan peduli dengan temannya, aktif dalam diskusi kelas serta tekun dalam mengerjakan tugas.

Belajar sambil menemukan unsur-unsur dari kata kunci itulah gambaran proses belajar mengajar yang teramati dalam penelitia ini. Peserta didik menjadi semangat dalam belajar, suasana kelas menjadi hidup, pendidik sudah bisa menjadi fasilitator dan motivator, lebih dari itu, terjadi peningkatan keterampilan peserta didik dalam menulis dan memahami konsep-konsep materi pembelajaran.

Di samping itu pola pembentukan kelompok yang memadukan antara pertimbangan pendidik dengan kemampuan peserta didik serta keinginan peserta didik menghasilkan kelompok yangharmonis. Antara peserta didik yang pandai dengan yang kurang pandai terjalin hubungan yang baik sehingga terjadi saling membantu dalam kegiatan diskusi . Pada akhirnya terjadi peningkatan hasil belajar peserta didik setelah tugas diberikan pendidik.

Hasil tugas akhir belajar pada kondisi awal sebelum diberikan tindakan hanya mencapai nilai rata-rata 68,55 dengan ketuntasan belajar hanya sebesar $75 \%$ (15 orang peserta didik yang mencapai KKM. Pada tugas akhir belajar siklus I mulai adanya peningkatan yaitu rata-rata nilai peserta didik 71,80 dengan jumlah peserta didik yang mencapai KKM 18 orang, namun masih terdapat 2 orang peserta didik yang belum mencapai KKM. Oleh sebab itu peneliti perlu melanjutkan siklus II dengan memperbaiki proses pembelajaran sesuai dengan hasil refleksi kegiatan siklus I. Pada siklus II rata-rata nilai peserta didik sudah mencapai 80,05, ini menunjukkan bahwa proses pembelajaran siklus II sudah menunjukkan peningkatan yang sangat tajam, di mana ketuntasan belajar sudah dicapai bahkan melebih target yang ditetapkan. Semua ini disebabkan oleh keterlibatan dan kesungguhan peserta didik dalam berdiskusi semakin tinggi. 
Peneliti/pendidik sudah berhasil memotivasi peserta didik sehingga minatnya semakin baik dalam diskusi untuk menyelesaikan tugas yang diberikan.

\section{KESIMPULAN DAN SARAN}

Berdasarkan hasil penelitian pembelajaran Menulis Teks Deskripsi Menggunakan Pendekatan Saintifik dengan Metode Mind Mapping diperoleh hasil sebagai berikut:

1. Pendidik dengan mudah membimbing peserta didik untuk dapat menulis teks deskripsi dengan metode peta pikiran tersebut.

2. Peserta didik tertarik dengan metode yang diberikan sehingga dengan mudah mereka bisa menulis teks deskripsi melalui pendekatan saintifik menggunakan metode mind mapping dengan media foto.

3. Terjadi peningkatan hasil belajar dari setiap siklus pelaksanaan penelitian.

4. Peserta didik termotivasi dan antusias untuk menyusun kalimat dengan metode peta pikiran.

5. Pendidik sudah terlihat terampil dalam mengelola kelas saat menggunakan metode mind mapping pada saat pembelajaran berlangsung.

Sehingga dapat disimpulkan bahwa penggunaan pendekatan saintifik dengan metode mind mapping dapat meningkatkan keterampilan peserta didik dalam menulis teks deskripsi secara signifikan.

Berdasarkan hasil penelitian tersebut, peneliti menyarankan agar:

1. Pendidik Bahasa Indonesia khususnya SMP Negeri 5 Kecamatan Lareh Sago Halaban diharapkan lebih berupaya menggunakan media yang bervariasi dalam pembelajaran.

2. Seluruh komponen sekolah diharapkan lebih meningkatkan kerjasama untuk mewujudkan tujuan pembelajaran dan melengkapi sarana dan prasarana.

\section{DAFTAR PUSTAKA}

Arsyad Azhar.1997. Media Pembelajaran. Jakarta:Raja Grafindo Persada.

Atmazaki.2006. Kiat-kiat Mengarang dan Menyunting. Padang:Citra Budaya.

Buzan, Tony dan Barry.2004. Memahami Peta Pikiran : The Mind Map Book Interaksa: Batam.

Buzan Tony. 2009. Buku Pintar Mind Mapping. Jakarta: PT. Gramedia Pustaka Utama.

Departemen Pendidikan Nasional.2003. Undang-Undang Nomor 20 Tahun 2003 Tentang Sistem Pendidikan Nasional, Jakarta: Depdiknas.

Finoza, Lamuddin. 2005. Komposisi Bahasa Indonesia. Jakarta: Diksi Insan Mulia.

Hartono, Bambang. 2012. Dasar-dasar Kajian Wacana. Semarang: Pustaka Zaman.

Semi, Atar. 2003. Menulis Efktif. Padang: Angkasa Raya. 